\title{
INTERVAL BETWEEN FIRST DOSE AND BOOSTER AFFECTED ANTIBODY PRODUCTION IN CATTLE VACCINATED AGAINST RABIES
}

\author{
ALBAS A. (1), FONTOLAN O. L. (2), PARDO P. E. (3), BREMER NETO H. (3), \\ SARTORI A. (2)
}

(1) Department of Tropical Diseases and Diagnostic Imaging, Botucatu School of Medicine, São Paulo State University, UNESP, Botucatu, São Paulo State, Brazil; (2) Department of Microbiology and Immunology, Institute of Biosciences, UNESP, São Paulo State University, Botucatu, São Paulo State, Brazil; (3) School of Veterinary Medicine, UNOESTE, Presidente Prudente, São Paulo State, Brazil.

ABSTRACT: In this study, we compared the levels of neutralizing antibodies induced by inactivated rabies vaccine in cattle by using three alternative immunization procedures. Forty-five bovines (breed nelore) were then organized in three groups (A, B and $C$, with 15 animals/group). Group A received only one vaccine dose at day zero and Group B received the first dose at day zero and then another dose at day 30 (early booster). Group C was also immunized with two doses; however, the booster was postponed until day 180 after the first dose (delayed booster). Blood samples were withdrawn at days zero (before the first dose) and 30, 210, 390, and 540 after the beginning of immunization and the antibody titers were evaluated by mouse neutralization test. The protocol used to immunize Group C (booster at day 180) was clearly more efficient. In this group, antibody levels were higher and also remained higher for longer periods in comparison with the other two groups. These results show that booster timing significantly affected antibody levels. Therefore, programs addressed to control this disease in cattle should consider not only the use of a booster but also its administration time.

KEY WORDS: rabies, vaccine, cattle, antibody, neutralization.

\section{CORRESPONDENCE TO:}

AVELINO ALBAS, Pólo Regional da Alta Sorocabana, APTA, Caixa Postal 298, Presidente Prudente, SP, 19001-970, Brasil. Email: avealbas@yahoo.com.br 


\section{INTRODUCTION}

Rabies is transmitted to cattle by different animals in different regions of the world. In Latin America, the vampire bat (Desmodus rotundus) is the main transmitter of this disease to livestock (7). According to information from the Brazilian Ministry of Agriculture, it is estimated that nearly 30,000 bovines are lost every year in Brazil due to this infection. Besides obvious economical costs, this high rabies incidence also increases the risk of rabies transmission to other animals (1). Extermination of vampire bat colonies with anticoagulants has been used to control rabies dissemination to cattle $(8,16)$. However, vaccination of bovine herds has been the most effective strategy to control the disease in bovines.

Studies have demonstrated that Brazilian inactivated vaccines are safer and are, at least, as efficient as attenuated live virus vaccines $(5,13)$. However, single doses of rabies vaccines have been associated with low levels of neutralizing antibodies and also with occurrence of disease in vaccinated animals $(9,15)$. On the other hand, the use of a booster has significantly increased antibody specific levels $(2,6,10,14,17)$. Based on these experimental observations, the Brazilian Program for Rabies Control in bovines has suggested the use of a booster to assure the induction of higher and therefore protective antibody levels. The choice of the timing for this booster is not very well established in cattle.

In the present study, we investigated the effect of a booster on the neutralizing antibodies level induced by an inactivated rabies vaccine (BGS-Cell) in bovines. Three distinct experimental groups were compared: Group A (only one vaccine dose); Group B (one dose plus one booster, 30 days apart); and Group C (one dose plus one booster, 180 days apart).

\section{MATERIALS AND METHODS}

\section{Animals}

Forty-five bovines (breed nelore) with approximately 1 year old, maintained in Boa Esperança Farm, Presidente Prudente, Brazil, were used. The animals were routinely inspected by a veterinarian and randomly distributed in 3 experimental groups ( $A, B$ and $C$ ) with 15 animals each and subjected to different immunization procedures. Swiss outbreed mice were used in neutralization assays to evaluate specific antibody levels induced by vaccination. 


\section{Rabies vaccine and immunization procedure}

Inactivated rabies virus (BGS-Cell) prepared from PV fixed virus grown on BHK-21 cell line and inactivated by $\beta$-propiolactone was kindly donated by Hertape Laboratory, Minas Gerais, Brazil. The vaccine (stock number 007/99) was adjuvanted with aluminum hydroxide and approved for use with an antigenic Habel value of $10^{8.08}$.

Bovines allocated in Groups $A, B$ and $C$ were initially immunized with one vaccine dose $(2 \mathrm{ml}$ ). Animals from Groups $B$ and $C$ received a booster (also $2 \mathrm{ml}$ ) after 30 and 180 days, respectively.

\section{Virus and serum samples}

The virus suspension to be used in mouse neutralization test (MNT) was prepared from the brain ( $20 \%$ homogenate in phosphate buffered saline) of mice infected with Challenge Virus Standard kindly donated by Laboratory of Animal Reference (LARA), Campinas, Brazil.

Blood samples from bovines were collected from the jugular vein before vaccination and also at days 30, 210, 390, and 540 after beginning the vaccination schedule.

\section{Mouse neutralization test (MNT)}

The MNT was done according to Fitzgerald (4), adopting the 5 -fold serial dilution. Swiss male and female mice weighing from 14 to $16 \mathrm{~g}$ were used. Titers were calculated by the Reed \& Müench method (11). Results were expressed using logarithmic transformation of the reciprocals of the dilutions, considering MNT titers < $0.5 \mathrm{IU} / \mathrm{ml}$ as non-reactants. A Berna International Standard Serum $(200 \mathrm{IU} / \mathrm{ml}$, lot number 137970103) was used as control. For statistical analysis, individual titers $(x)$ were subjected to logarithmic transformation, using $\log _{10}(x+1)$ and then analyzed by ANOVA and unpaired t test, using $\alpha=0.05$ (12).

\section{RESULTS}

Individual antibody titers observed in animals from Groups A, B and C are shown in Tables 1, 2 and 3, respectively.

Thirty days after administration of the first rabies vaccine dose, all animals, except one (number 44), produced significant amounts of specific antibodies detected by MNT. Antibody levels were similar, as expected, in the three groups and geometric 
mean titers were: 4.93, 5.92 and 3.63 in Groups A, B and C, respectively. The percentage of titers $\geq 0.5 \mathrm{IU} / \mathrm{ml}$ was $100 \%$ in Groups A and B and $93 \%$ in Group C. At day 210, there was a significant increase in the geometric mean titer in Group $C$ (26.96) in comparison with Groups A (1.85) and B (1.93). At this period, the percentage of titers $\geq 0.5 \mathrm{IU} / \mathrm{ml}$ was equally high in the three groups: 93.3, 93.3 and $100 \%$ in Groups A, B and C, respectively. At day 390, a significant drop in the geometric mean titers was observed in Group $C$ comparing with day 210. However, this value was still significantly higher than the ones observed in Groups A and B. The percentage of titers $\geq 0.5 \mathrm{IU} / \mathrm{ml}$ was also significantly higher $(100 \%)$ than the ones detected in Groups A (86.6\%) and B (73.3\%). At day 540, the geometric mean titers were similar among the three groups: $1.29,1.48$ and 1.64 in Groups A, B and $C$, respectively. However, in Group $C$ all animals had titers higher than $0.5 \mathrm{IU} / \mathrm{ml}$, comparing with Groups A (46.6\%) and B (66.6\%). 
Table 1: Virus neutralizing antibody (VNA) titers in cattle immunized with a single dose of rabies inactivated vaccine (Group A)

\begin{tabular}{|c|c|c|c|c|c|}
\hline \multirow{3}{*}{$\begin{array}{l}\text { Animal } \\
\text { Number }\end{array}$} & \multicolumn{5}{|c|}{ VNA } \\
\hline & Day & Day 30 & Day 210 & Day 390 & Day 540 \\
\hline & zero & & & & \\
\hline 01 & 0 & 3.31 & 0.56 & 0.79 & 0 \\
\hline 02 & 0 & 5.62 & 1.09 & 1.09 & 0 \\
\hline 03 & 0 & 4.17 & 1.00 & 0.50 & 0 \\
\hline 04 & 0 & 5.62 & 0.79 & 0.50 & 0.50 \\
\hline 05 & 0 & 1.09 & 0.89 & 0.89 & 0.60 \\
\hline 06 & 0 & 1.99 & 0.89 & 0.50 & 0.50 \\
\hline 07 & 0 & 3.31 & 0.89 & 0.56 & 0 \\
\hline 08 & 0 & 1.41 & 1.09 & 1.09 & 0 \\
\hline 09 & 0 & 16.22 & 1.28 & 1.09 & 0.89 \\
\hline 10 & 0 & 0.60 & 0 & 0 & 0 \\
\hline 11 & 0 & 5.62 & 0.89 & 0.89 & 0 \\
\hline 12 & 0 & 1.41 & 0.56 & 0 & 0 \\
\hline 13 & 0 & 5.62 & 1.09 & 1.28 & 0.89 \\
\hline 14 & 0 & 22.9 & 1.09 & 1.09 & 0.89 \\
\hline 15 & 0 & 4.57 & 1.09 & 1.09 & 0.89 \\
\hline $\begin{array}{c}\text { Geometric mean } \\
\text { titer }\end{array}$ & 1.0 & 4.93 & 1.85 & 1.71 & 1.29 \\
\hline$\%$ titer $\geq 0.5 \mathrm{lU} / \mathrm{ml}$ & 0.0 & 100 & 93.3 & 86.6 & 46.6 \\
\hline
\end{tabular}

Titers in IU/ml

For statistical analysis, transformation of $\log _{10}(x+1)$ 
Table 2: Virus neutralizing antibody (VNA) titers in cattle that received a booster 30 days after the primary immunization (Group B)

\begin{tabular}{|c|c|c|c|c|c|}
\hline & \multicolumn{5}{|c|}{ VNA } \\
\hline Animal & Day zero & Day 30 & Day 210 & Day 390 & Day 540 \\
\hline \multicolumn{6}{|l|}{ Number } \\
\hline 16 & 0 & 3.31 & 1.00 & 0 & 0 \\
\hline 17 & 0 & 1.41 & 1.41 & 0 & 0 \\
\hline 18 & 0 & 1.69 & 0.50 & 0 & 0 \\
\hline 19 & 0 & 16.22 & 1.38 & 0.89 & 0.89 \\
\hline 20 & 0 & 22.9 & 1.38 & 1.09 & 0.89 \\
\hline 21 & 0 & 5.75 & 1.09 & 0.79 & 0.60 \\
\hline 22 & 0 & 4.67 & 1.41 & 1.09 & 1.09 \\
\hline 23 & 0 & 0.89 & 0.89 & 0.89 & 0 \\
\hline 24 & 0 & 12.59 & 1.09 & 1.09 & 1.09 \\
\hline 25 & 0 & 8.71 & 1.41 & 0.89 & 0.89 \\
\hline 26 & 0 & 22.90 & 0.79 & 0.79 & 0.79 \\
\hline 27 & 0 & 0.60 & 0 & 0 & 0 \\
\hline 28 & 0 & 1.91 & 0.69 & 0.69 & 0.60 \\
\hline 29 & 0 & 4.67 & 0.60 & 0.79 & 0.60 \\
\hline 30 & 0 & 4.57 & 1.09 & 1.09 & 0.60 \\
\hline $\begin{array}{c}\text { Geometric mean } \\
\text { titer }\end{array}$ & 1.0 & 5.92 & 1.93 & 1.61 & 1.48 \\
\hline$\% \geq 0.5 \mathrm{IU} / \mathrm{ml}$ & 0.0 & 100 & 93.3 & 73.3 & 66.6 \\
\hline
\end{tabular}

Titers in IU/ml

For statistical analysis, transformation of $\log _{10}(x+1)$ 
Table 3: Virus neutralizing antibody (VNA) titers in cattle that received a booster 180 days after the primary immunization (Groups C)

\begin{tabular}{|c|c|c|c|c|c|}
\hline & \multicolumn{5}{|c|}{ VNA } \\
\hline Animal & Day zero & Day 30 & Day 210 & Day 390 & Day 540 \\
\hline \multicolumn{6}{|l|}{ Number } \\
\hline 31 & 0 & 0.60 & 22.91 & 1.28 & 0.69 \\
\hline 32 & 0 & 9.55 & 20.89 & 1.91 & 0.50 \\
\hline 33 & 0 & 6.46 & 46.77 & 5.62 & 1.41 \\
\hline 34 & 0 & 3.71 & 28.18 & 4.46 & 1.00 \\
\hline 35 & 0 & 1.09 & 36.30 & 0.79 & 0.69 \\
\hline 36 & 0 & 1.91 & 20.42 & 4.07 & 1.09 \\
\hline 37 & 0 & 1.09 & 5.49 & 0.60 & 0.50 \\
\hline 38 & 0 & 5.62 & 22.38 & 1.09 & 0 \\
\hline 39 & 0 & 3.31 & 29.51 & 1.91 & 0.69 \\
\hline 40 & 0 & 1.09 & 46.77 & 5.62 & 1.41 \\
\hline 41 & 0 & 20.89 & 46.77 & 5.62 & 1.51 \\
\hline 42 & 0 & 0.60 & 36.30 & 1.09 & 0.69 \\
\hline 43 & 0 & 7.24 & 36.30 & 6.76 & 1.41 \\
\hline 44 & 0 & 0 & 18.62 & 5.49 & 0.79 \\
\hline 45 & 0 & 0.89 & 16.23 & 0.89 & 0.60 \\
\hline $\begin{array}{c}\text { Geometric mean } \\
\text { titer }\end{array}$ & 1.0 & 3.63 & 26.96 & 2.08 & 1.64 \\
\hline$\% \geq 0.5 \mathrm{lU} / \mathrm{ml}$ & 0.0 & 93.3 & 100 & 100 & 93.3 \\
\hline
\end{tabular}

Titers in IU/ml

For statistical analysis, transformation of $\log _{10}(x+1)$

\section{DISCUSSION}

Recent reports have demonstrated that Brazilian inactivated vaccines against rabies in bovines are, at least, as efficient as attenuated live virus vaccines $(5,13)$. Recently, Rodrigues da Silva (14) compared both vaccines and observed a better performance of the inactivated type. This better performance was attributed, at least partially, to the fact that the inactivated vaccine was administered in two doses with an interval of 30 days. 
In this context, the efficacy of three alternative vaccination procedures, employing the inactivated BGS-Cell vaccine was compared. Three experimental groups were used: Group A: only one vaccine dose; Group B: two doses given 30 days apart; and Group C: two doses given 180 days apart. The humoral immune response was evaluated in bovine serum samples by using the mouse neutralization test (MNT). MNT results were analyzed according to the World Health Organization, which established values $\geq 0.5 \mathrm{IU} / \mathrm{ml}$ as indicators of protection, being necessary the administration of a booster if the value is under this limit (18).

By checking the presence of specific antibodies in samples collected before the immunization procedure, we certified that all animals were free of specific rabies antibodies and could, therefore, be included in the study.

The antibody profile was very similar between Groups A and B during almost all periods of investigation. In addition, a significant drop in antibody titers was detected at days 210, 390 and 540 . These results show that a booster given 30 days after the first dose was not improving the humoral response as expected.

Interestingly, the antibody profile observed in Group $C$ was very distinct from that of Groups A and B. As expected, there was a significant increase in antibody titers at day 210 (30 days after the booster). In this case, the percentage of titers $\geq 0.5 \mathrm{IU} / \mathrm{ml}$ was $93.3 \%$ and therefore much higher than the values detected in the two other groups. This observation is very interesting not only because it is original but also because it has a very important application in the field of animal health. The Brazilian Program for Rabies Control has suggested the use of a booster in cattle vaccination. However, the most adequate period for this second dose was not appropriately investigated until now. Our results indicate, therefore, that a latter booster, given for example at 180 days after the first vaccine dose, is more adequate than an earlier booster, because it triggers a higher and long lasting immune response.

A direct comparison of our results with other reports in this field is not possible because different immunization schedules were used. However, other investigators also observed a beneficial effect from boosters. For example, Umehara et al. (17) evaluated the antibody response of cattle vaccinated at days 0,90 and 360 with two vaccine types: associated with aluminum hydroxide or Avridine. The two vaccines induced antibody responses with titers that persisted above 2,264 $\log _{10} S_{50}$ throughout the study. Similar results were observed by Côrtes et al. (3). 
One aspect that we considered very relevant in this work was the extended period of serum antibody levels evaluation. A few authors have done this prolonged follow up. Even though we restricted this evaluation to the inactivated vaccine donated by Hertape Laboratory, we believe that other factors can also modify the final result. Therefore, factors as kind of vaccine (inactivated or attenuated), manufacturer, stock conditions, and mainly the antigenic vaccine value must be checked before the adoption of a certain vaccine schedule.

The molecular and cellular mechanisms that determined a better response in Group C (delayed booster) in comparison with Group B (early booster) were not investigated. One possibility is that at day 30 the amount of antigen from the first dose was still enough for a good immune response. In this case, an extra antigen supply would not induce a better response. Another possibility, that does not exclude the first one, is that memory cells were not fully developed after 30 days from the first vaccine dose. In this case, the antigen would not interact with memory cells and, consequently, would not induce an anamnestic immune response. In addition, we could think that at day 30 the anti-rabies antibody levels were still too high and could neutralize the injected antigen.

These results support the Brazilian Program for Rabies Control that stresses the need of a booster. In addition, these results alert for the necessity to check the best moment to give the booster in rabies prophylaxis.

\section{REFERENCES}

1 ACHA PN., MALAGA-ALBA A. Economic losses due to Desmodus rotundus. In: GREENHALL AM., SCHMIDT U. Eds. Natural history of vampire bats. Boca Raton: CRC Press, 1988: 207-14.

2 ALBAS A., PARDO PE., GOMES AA., BERNARDI F., ITO FH. Effect of a boosterdose of rabies vaccine on the duration of virus neutralizing antibody titers in bovines. Rev. Soc. Bras. Med. Trop., 1998, 31, 367-71.

3 CÔRTES JA., RWEYEMAMU MM., ITO FH., UMEHARA O., MEDEIROS NETO RR., DE LUCCA NETO D., BALTAZAR MC., VASCONCELLOS SA., VASCONCELLOS MEP. Immune response in cattle induced by inactivated rabies vaccine adjuvanted with aluminium hydroxide either alone or in combination with avridine. Rev. Sci. Tech., 1993, 12, 941-55. 
4 FITZGERALD EA. Potency test for antirabies serum and immunoglobulin. In: MESLIN FX., KAPLAN MM., KOPROWSKI H. Eds. Laboratory techniques in rabies. 4. ed. Geneva: World Health Organization, 1996: 417-22.

5 GUIDOLIN R., BALTAZAR MC., ZELANTE F. Produção da vacina anti-rábica veterinária em suspensão de células BHK. Rev. Microbiol., 1983, 14, 27-35.

6 ITO FH., CÔRTES JA., RWEYEMAMU MM., UMEHARA O., MEDEIROS NETO R., DE LUCCA NETO D., BALTAZAR MC., VASCONCELLOS SA., VASCONCELLOS MEP. Course of secondary humoral immune response shortly after revaccination with BHK-21 cell culture inactivated rabies vaccine adjuvanted with aluminum hydroxide. Braz. J. Vet. Res. Anim. Sci., 1991, 28, 51-7.

7 LARGHI OP., NEBEL AE. Duration of immunity afforded to cattle by a binaryethylenimine inactivated rabies vaccine. Zentralbl. Veterinarmed. B., 1985, 32, 609-15.

8 LINHART SB., FLORES RC., MITCHELL G. Control de murciélagos vampiros por medio de un anticoagulante. Bol. Oficina Sanit. Panam., 1972, 73, 100-9.

9 MONTAÑO JA., POLACK GW., MORA EF. Raiva bovina em animais vacinados. II. Situação epidemiológica no Estado do Paraná, Brasil - 1984. Arq. Biol. Tecnol., 1987, 30, 367-80.

10 OLIVEIRA AN., ANDRADE MCR., SILVA MV., MOURA WC., CONTREIRAS EC. Immune response in cattle vaccinated against rabies. Mem. Inst. Oswaldo Cruz, 2000, 95, 83-8.

11 REED LJ., MÜENCH H. A simple method of estimating fifty per cent endpoints. Am. J. Hyg., 1938, 27, 493-7.

12 REMINGTON RD., SCHORK MA. Statistics with application to the biological and health sciences. New Jersey: Prentice-Hall, 1970. 418p.

13 RIBEIRO NETO A., NILSSON MR., CÔRTES JA., MIZUMO M., MIGUEL O. Comparative study of cattle antirabies vaccines. II. Protection conferred by Alurabifa, ERA and Formidogel vaccines. Zentralbl. Veterinarmed. B, 1973, 20, 378-404.

14 RODRIGUES DA SILVA AC., CAPORALE GM., GONÇALVES CA., TARGUETA MC., COMIN F., ZANETTI CR., KOTAIT I. Antibody response in cattle after vaccination with inactivated and attenuated rabies vaccines. Rev. Inst. Med. Trop. S. Paulo, 2000, 42, 95-8. 
15 RONDON ES., BASTOS PV., SILVA DA., PICCINI RS. Estudo comparativo da sintomatologia clínica de bovinos suspeitos de raiva. Rev. Bras. Med. Vet., 1995, 17, 253-9.

16 THOMPSON RD., MITCHELL GC, BURNS RJ. Vampire bat control by systemic treatment of livestock with an anticoagulant. Science, 1972, 177, 806-8.

17 UMEHARA O., DE LUCCA NETO D., MORO E., BERNARDI F., ITO FH., RODRIGUES CA. Rabies virus neutralizing antibody profile in cattle vaccinated with inactivated vaccine adjuvanted with either aluminium hydroxide alone or combined with avridine. Arq. Inst. Biol., 2002, 69, 23-8.

18 WORLD HEALTH ORGANIZATION. Expert Committee on Rabies. Geneva: World Health Organ., 1992. (WHO Tech. Rep. Ser., 824, 1-84). 